\title{
Pulmonary immune responses induced in BALB/c mice by Paracoccidioides brasiliensis conidia
}

\author{
Angel González • Angela Restrepo $\cdot$ Luz Elena Cano
}

Received: 9 July 2007 / Accepted: 2 October 2007

(C) Springer Science+Business Media B.V. 2007

\begin{abstract}
Knowledge concerning the host-Paracoccidioides brasiliensis interactions is abundant. Yet, most of the experimental studies have used yeast cells to prepare the corresponding inoculum. As these cells do not represent the naturally infecting propagules, the corresponding experiments by-pass the earlier stages of such interactions. Studies done in patients, who also harbour yeast cells, suffer from the same bias. The review presented below focuses on the immune responses of BALB/c mice infected with conidia obtained from $P$. brasiliensis mycelial form cultures, the fungal stage most probably existing in nature. As such, the corresponding experiments would copy the onset and course of the human infection. A large number of experimental studies done by the CIB Medical and Experimental Mycology Unit in a period of almost 25 years have been revised and extracted so as to present a comprehensive record on the immune responses induced when mice are infected intranasally with the conidia. The establishment of this mouse model has permitted the analysis of the immune responses taking place during the early and late stages post-challenge. This unique
\end{abstract}

A. González · A. Restrepo · L. E. Cano ( $\square)$

Medical and Experimental Mycology Group, Corporación para Investigaciones Biológicas, CIB, Medellin, Colombia e-mail:1cano@cib.org.co

A. González · L. E. Cano

Molecular Microbiology Group, School of Microbiology,

University of Antioquia, Medellin, Colombia model has made possible to characterize the course of the experimental disease including the inflammatory reaction, the expression of cytokines and of the various molecules associated to these responses, all of which lead to granuloma formation. The latter structure serves as a nest for the development of fibrosis. Thus, we have also obtained a glimpse on the complexity that accompanies the fibrosis, the most common sequelae of paracoccidioidomycosis. Additionally, a concerted effort has been made to appraise the whole gamut of immune factors and related molecules that directly or indirectly, contribute to shape the pathogenesis of this Latin American mycosis.

Keywords Paracoccidioides brasiliensis . Conidia $\cdot$ Immune response $\cdot$ Experimental paracoccidioidomycosis $\cdot$ Fibrosis

\section{Introduction}

Animal models constitute excellent tools to study the immune responses to fungal pathogens [1-3]. More than 20-years ago, animal models were used to measure the immune responses in PCM, initially in hamsters [4, 5], mice [6-9], and then in guinea pigs $[10,11]$ and bats [12]. Additionally, a recent study has utilized dogs to explore certain immune functions [13].

Experimental studies done with other pathogenic fungi have revealed that in infected animals, the route 
of infection influences their response profiles [2]. This was confirmed in experimental models of PCM; thus, the use of diverse routes of infection, the varying challenge doses, and the lack of quantitation have interfered with evaluation of the data [5, 6, 14-20].

Several research groups have developed mouse models of this mycosis, and studied the host defence mechanism against $P$. brasiliensis [6, 7, 21-23]. A greater insight into the immune response elicited by P. brasiliensis has come from the use of murine models. Calich et al. [24] developed an isogenic murine model of PCM, where B10.A mice were susceptible to, and $\mathrm{A} / \mathrm{Sn}$ mice were resistant to $P$. brasiliensis. However, development of an animal model simulating the fatal human disease, including the pulmonary portal of entry, has not been successful. Some investigators had been able to establish pulmonary and disseminated infections in normal mice by intratracheal or intranasal administration of $P$. brasiliensis yeast cells. However, the lack of quantization and characterization of the inocula have limited the reproducibility and utility of these systems [6].

A common approach in these studies has been the use of the microorganism's tissue-invasive yeast cells. While such studies allowed evaluation of both the course of dissemination and the immune characteristics of the established infection, they were unable to determine the crucial early events occurring when the naturally infecting propagules reached the air spaces [15].

Nonetheless, the exact mechanism of infection continues to be a matter of debate mainly due to lack of knowledge concerning the natural habitat of the fungus [25]. Considering that PCM is acquired through the respiratory route [26], our group has developed a mouse model that reproduces human infection from its inception. The naturally infecting propagules conidia, are given intranasally to the animals, mimicking a naturally acquired infection. In this PCM model, the early inflammatory stages are characterized by few macrophages and abundant PMN, and also, by changes in the reticular stroma of the lungs' interstitium with formation of fibrotic scars $[15,27]$. In addition, this model has permitted detailed observation of not only the characteristics of the inflammatory response evoked by $P$. brasiliensis conidia but also the constitutive elements of fibrosis [15, 27, 28].

Even if the early inflammatory response is nonspecific, such a stage is important because it is just at this moment that the resident pulmonary macrophages interact with the fungus for the first time and become activated proceeding to stimulate recruitment of other inflammatory cells [27-30]. In summary, the observations described above establish the value of this animal model for studies of the immune responses in PCM, and may contribute to designing new, more far reaching experiments.

\section{Development of pulmonary paracoccidioidomycosis in an experimental murine model}

The intranasal Infection of BALB/c male mice with $P$. brasiliensis conidia provides a uniform and highly reproducible model of both early stages and chronic pulmonary PCM. Our group has been using this model to study the various mechanisms participating in the early events such as adhesion and proinflammatory process, as well as the immune response of the fibrous processes leading to granuloma formation.

In PCM, and in other deep mycosis, the course and control of the infection are mainly determined by the interaction between the invading fungus and the various host defence mechanisms. In our PCM murine model, the sequential histophatological studies have revealed the kinetics of the inflammatory response consisting of three stages: (i) a neutrophilic or monocyte-neutrophilic stage, in which PMN and histiocytes are present, witnessing the early inflammatory process; (ii) a mixed granulomatous stage, in which epithelioid granulomata run in parallel with the presence of PMN and (iii) a granulomatous and fibrous-fibroblastic stage, characterized by presence of abundant giant cells, histiocytes, macrophages and fibrous conjunctive tissue [27, 28, 31, 32].

\section{Immune responses during the early stages of pulmonary infection with $\boldsymbol{P}$. brasiliensis conidia}

As described below, it has been observed that during the early stages of infection induced by different fungal propagules (conidia, yeasts or their fragments), the inflammatory infiltrate is composed mainly by PMNs and macrophages [14, 21, 27-30, 33, 34]. 
Characteristics of the acute inflammatory response

Histopathologically, and during the initial post-challenge periods, the lungs of mice infected with P. brasiliensis conidia, present a brochopneumonic, acute type response with PMNs accumulation that fuse with each other constituting extensive, illdefined masses, mainly at the peribronchiolar level $[28,30]$. Initially, during these early stages postchallenge, an afflux of PMNs is observed, which changes towards a lympho-histo-plasmocytic infiltrate, finally leading to granuloma formation $[28,30]$.

Concerning the fungus, the majority of the yeasts appear associated with inflammatory cells, consisting largely of PMNs and macrophage's aggregates. Finally, at the end of second week, when granulomata become established, yeast cells are not only numerous inside such structures, but are also in active multiplication and appear intermingled with PMNs [30].

\section{Inflammatory cells}

In situ, the pulmonary inflammatory response evoked in mice after infection with $P$. brasiliensis conidia reached its maximum between days 2 and 3, when $40-42 \%$ of the lungs' area was involved. Nonetheless, at the end of the second week, a decrease on these values (about $8 \%$ of inflammatory areas) could be noticed $[27,28,30]$.

Two hours after infection, no inflammatory cells were observed in the lungs; however, $24-48 \mathrm{~h}$ postchallenge increased numbers of PMNs (over 90\%) appeared dispersed among the inflammatory infiltrate (Fig. 1b). On the third and fourth days post-infection, the inflammatory cells' composition consisted of a pool of PMNs and macrophages located inside the alveolar spaces and surrounding the peribronchial vessels (Fig. 1c) [27, 28, 30]. Conversely, in the mononuclear cells, during the early periods, it increased and reached high, stable levels (above $80 \%$ ) after 4 day post-infection [28, 30].

Monocyte/macrophages play an important role in host defence. They are implicated in innate resistance mechanisms against fungi via both their direct fungicidal capacity and synthesis of cytokines, such as tumour necrosis factor alpha (TNF- $\alpha$ ) exerting a beneficial effect in the prevention of fungal infections [35-39]. Macrophages are main source of both TNF$\alpha$ and interleukin-1 (IL-1), cytokines that mediate both local and systemic inflammatory responses [35, 38, 39]. On the other hand, granulocytes, mainly PMNs, are the first cells to migrate into tissues in response to invading pathogens. It has long been recognized that their main role in the inflammatory and immune responses is accomplished through phagocytosis and killing of micro-organisms via the generation of reactive oxygen intermediates (ROI) and the release of the lytic enzymes stored in their granules [40].

Eosinophils and lymphocytes have also been detected at the perivascular level during the second and third day post-infection (Fig. 1d, e) [30]. Eosinophils are considered to be effector cells, which in the presence of antibodies or complement, are able to kill parasites [41-46]. The role of eosinophils in the immune response to fungal infections has not been extensively studied. However, Wagner et al. [47] described in human samples that eosinophils were observed in direct association to or nearby P. brasiliensis. Nonetheless, in the majority of the corresponding publications, these cells were ignored, something that could be attributed to the fact that the haematoxylin and eosin stain often fails to show the presence of these cells [47]. In our model, we used special stainings such as Sirius Red to determine the presence of eosinophils (Fig. 1d) [30]. As it concerns lymphocytes, these cells could represent subpopulations of CD4, CD8 or NK cells, all of them capable of producing interferon gamma (IFN- $\gamma$ ) [48-50], described as the most important cytokine exerting a protective role in pulmonary PCM [51, 52]. In addition, it has been shown that in both susceptible and resistant mice, the depletion of CD8 $\mathrm{T}$ cells induces impairment of host defence against pulmonary PCM [53]. At this moment, however, the role of CD4 $\mathrm{T}$ cells has not been elucidated. In another study, NK cells were unable to control fungal infection [54].

We have also observed that after intranasal challenge with $P$. brasiliensis conidia, the cellularity of bronchoalveolar lavage fluid (BAL) increased [29]. The majority of these pro-inflammatory leukocytes in BAL fluids of infected mice were PMNs. Accordingly with the above description, these cells were present during the first 4 days post-inoculation 
Fig. 1 Histological aspects of pulmonary tissues from mice intranasally inoculated with $4 \times 10^{6} P$. brasiliensis conidia. Stains used: H\&E $(\mathbf{a}-\mathbf{c}, \mathbf{e}, \mathbf{f})$, Sirius red (d) and Grocott-PMA-PSR (phosphomolybbdic acidpicrosirius red), analysed by confocal laser scanning microscopy (CLSM) (g, h). (a) At day 0, lack of inflammatory infiltrates. (b) At day 1 post-infection, lungs of infected mice had an increase in neutrophils, preferentially located within the alveolar spaces. (c) At day 4 , a predominantly macrophagic accumulation was observed. (d)

Eosinophils and (e)

lymphocytes were observed at the periarterial level after the second and third days post-infection, respectively. (f) At week 4, the infiltrates were composed by macrophages and lymphocytes surrounding $P$. brasiliensis yeast cells forming a granuloma. $(\mathbf{g}, \mathbf{h})$ Determination of collagen expression at weeks 4 and 12 , respectively. Sequential increase in number and thickness of collagen fibres are observed in red with fungi in black
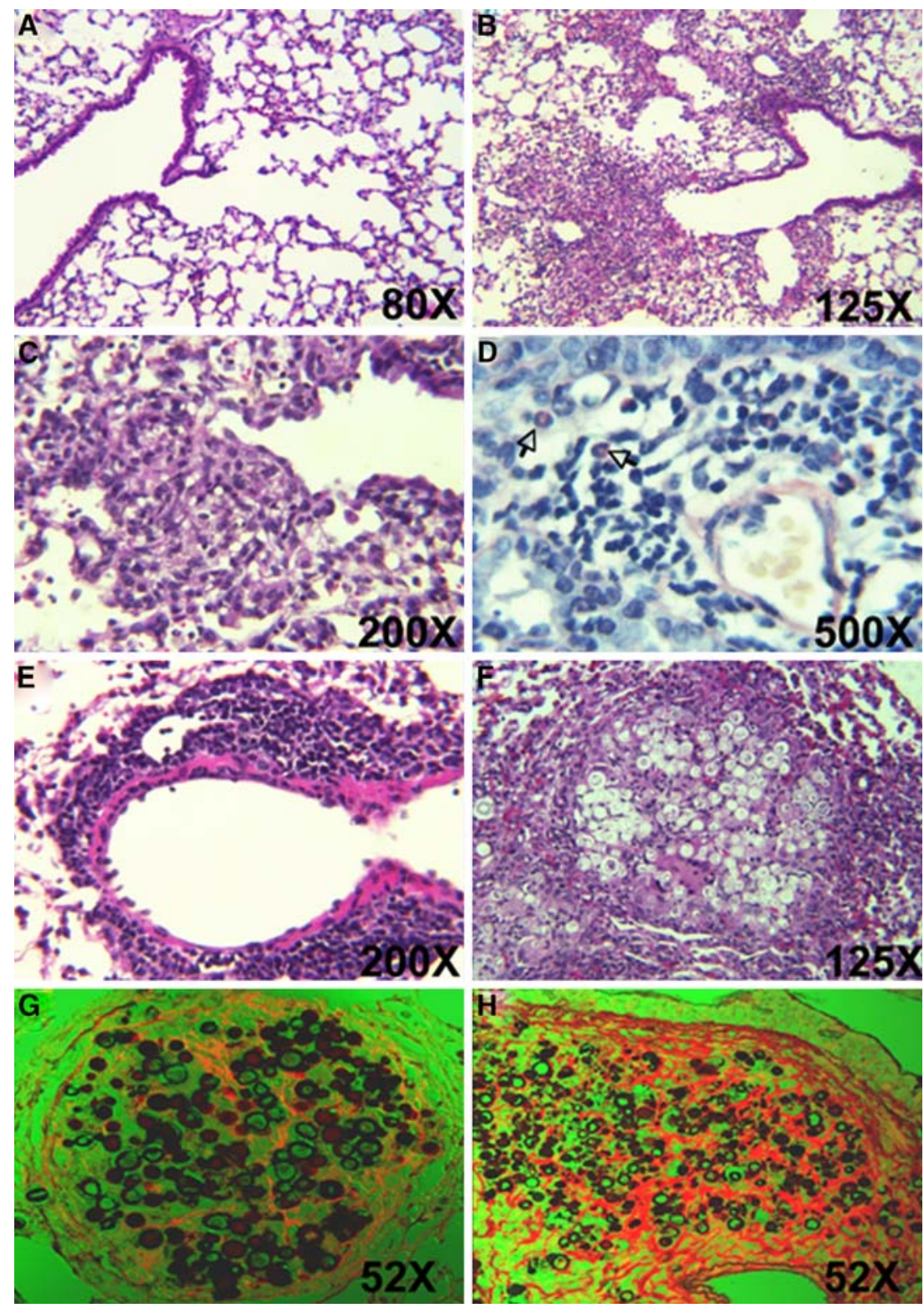

with a maximal value being observed at day 2 . Nonetheless, macrophages increased significantly in infected animals at day 2 and reached their maximal number at day 4. Along the same line, lymphocytes were observed only in infected mice with a maximum value at day 4 . These determinations coincided with the in situ description [29]. Similar results were described by Pina et al. [55], who inoculated P. brasiliensis yeast cells in C57BL/6 mice and analysed the BAL fluid after infection. At $48 \mathrm{~h}$ post-challenge, they found an increase in the number of total cells, mainly due to PMN leukocytes influx in the BAL fluid. These results are consistent with other experimental models using medical important fungi such as Candida albicans, Aspergillus fumigatus and Pneumocystis carinii [56-59], where it has been demonstrated that the recruitment of PMNs occurs during first day post-challenge, and that this recruitment is mediated by pro-inflammatory cytokines including TNF- $\alpha$, IL- 6 , IL- $1 \beta$ and granulocyte-macrophage colony stimulating factor (GM-CSF). As described below, in this model of pulmonary PCM, 
we found higher production of pro-inflammatory cytokines during the early stages of infection, which appear responsible for this leukocyte recruitment into the lungs [29].

Finally, in our model, we have observed a significant decrease in colony forming units (CFUs) after the first 2 days post-challenge [30]. Similar results had been observed previously using susceptible and resistant mouse strains inoculated intratracheally with P. brasiliensis yeasts [60].

\section{Pro-inflammatory cytokines}

The phagocytic cells are the primary source of several pro-inflammatory cytokines that mediate both the local and systemic inflammatory responses [35, $38,39]$. It is well established that the expression of pro-inflammatory cytokines by macrophages or endothelial cells results in recruitment of leukocytes; subsequently, the latter adhere to infected tissues by means of adhesion molecules [38]. It has also been shown that TNF- $\alpha$ is one of the cytokines produced during the first week of the experimental PCM infection [61]. Besides, in other studies, it has been shown that this pro-inflammatory cytokine plays a crucial role in resistance to $P$. brasiliensis yeast cells infection [52, 62]. In vitro, other pro-inflammatory cytokines such as GM-CSF and IL- $1 \beta$ have also been shown capable of inducing fungicidal/fungistatic activity in both human and murine PMNs directed against $P$. brasiliensis yeast cells [63-65].

In addition, PMNs are able to synthesize IL- $1 \beta$, IL-8, TNF- $\alpha$, transforming growth factor beta (TGF- $\beta$ ), macrophage inflammatory protein-1-alpha (MIP-1 $\alpha$ ), GM-CSF and IFN- $\alpha$ [40], thus contributing to this stage of the host-parasite interaction. BALB/c mice respond to conidial intranasal infection by recruiting leukocytes into the lungs accompanied by a significant elevation of pro-inflammatory cytokines TNF- $\alpha$, IL-6 and IL- $1 \beta$, as well as with MIP-2 chemokine. The highest levels of these cytokines were found during the first 4 days in BAL fluids and lung homogenates, but not in sera, indicating that these molecules predominated in the pulmonary compartments [29]. It is well established that the production of these pro-inflammatory cytokines by both inflammatory and endothelial cells results in recruitment of leukocytes indirectly, through the induction of adhesion molecules' expression mediating transmigration of the inflammatory cells into the injured tissue [38]. In our model of conidia-induced pulmonary PCM, the higher cytokine levels at this site, in combination with PMNs and macrophages increases, suggest that these factors play an important role in the innate resistance to $P$. brasiliensis.

On the same token, in BALB/c mice, the high levels of these cytokines detected during first day post-challenge with $P$. brasiliensis conidia, have also been documented in vivo and in vitro in other models, and appear to play an important role in the control of fungal infections produced by $C$. albicans, A. fumigatus, Cryptococcus neoformans and Coccidioides immitis [66-69].

\section{Expression of adhesion molecules}

The adhesion process constitutes the initial phase of the host-parasite interaction, whereby endothelial cells induce leukocyte migration into infected tissue; this is a three-step process that includes rolling, mediated by selectins and their carbohydrate ligands [70], followed by attachment and finally, by migration; the latter two events are mediated by integrins and adhesion molecules belonging to the immunoglobulin gene family [71]. Interactions between these molecules are crucial in promoting strong leukocyte adherence to vascular endothelium thereby permitting trafficking in the postcapillary venules and transmigration into injured tissues. Intracellular adhesion molecule-1 (ICAM-1) is a member of the immunoglobulin family, and is expressed on the surface of several cells including both endothelial and epithelial cells, platelets and mononuclear cells [72-74]. On the other hand, pro-inflammatory cytokines, such as TNF- $\alpha$ and IL-1- $\alpha$, stimulate the expression of endothelial adhesion molecules: ICAM-1, vascular cell adhesion molecule-1 (VCAM-1), and endothelial leukocyte adhesion molecule-1 (ELAM-1), which are important modulators involved in the recruitment of leukocytes into inflammatory sites [75, 76].

These adhesion molecules have been previously implicated in the inflammatory component of several lung diseases including asthma [77], sarcoidosis [73], tuberculosis [78] and infections produced by fungi such as C. neoformans [79], P. carinii [80], A. fumigatus [81] and C. albicans [82, 83]. Recently, 
the expression of adhesion molecules in the lungs of mice infected with $P$. brasiliensis conidia has been demonstrated during the early stages of infection [30]. An increase in ICAM-1 was observed during first four days on bronchiolar epithelium, pneumocytes and macrophages, as well as on vascular endothelium during first 2 days; however, ICAM-1 was observed constitutively in the lungs of control animals. ICAM-1 endothelial expression promotes adherence, activation and subsequent recruitment of inflammatory cells, especially PMNs and mononuclear cells [84]. Consistent with the above, an increase in the production of pro-inflammatory cytokines, as well as of PMNs and macrophages, has been observed at time of development of the inflammatory response to $P$. brasiliensis infection [29, 30].

VCAM-1 has been observed only in the vascular endothelium of infected mice. This adhesion molecule is increased, and is rapidly induced (18-24 h postchallenge) after cellular activation with IL- 1 , TNF- $\alpha$ or IL-4 [85-88]. VCAM-1 serves a receptor to VLA4 , an integrin expressed in monocytes, lymphocytes and eosinophils $[85,86,89,90]$. In the present model, we observed that this adhesion molecule was expressed in vascular endothelial cells during the first 2 days post-infection, at the time when eosinophils and lymphocytes became present [30].

In addition, the $\beta 2$ integrins, CD18 and Mac-1, but not lymphocyte function-associated antigen-1 (LFA-1) were strongly expressed by cells present in the inflammatory infiltrates, especially on PMNs and macrophages, suggesting that the participation of Mac- 1 is more important than that of LFA-1 for the recruitment of PMNs and macrophages into the lungs of infected mice [30].

The results described above suggest that the expression of cellular adhesion molecules has bearings on the pathogenesis of PCM, and their up-regulation could be associated by overproduction of pro-inflammatory cytokines such as TNF- $\alpha, \mathrm{IL}-1 \beta$ and IL-6, among others.

In human studies, Fornazim et al. [91], found increased number of lymphocytes and PMNs in BALs of patients with PCM. In this study, the alveolar macrophages over expressed ICAM-1, and other molecules on their surfaces, and they produced higher levels of IL- 6 , TNF- $\alpha$ and MIP- $1 \alpha$, indicating their participation in the pathogenesis of pulmonary PCM [91].

\section{Expression of extracellular matrix proteins}

Extracellular matrix (ECM) proteins are considered to be essential constituents of tissues' support structures, and being important modulators of migration, differentiation, proliferation and function of the various cell types present into the lungs. In addition, these ECM proteins influence directly or indirectly the immune response including the inflammatory process [92-94]. Therefore, it has been reported that ECM proteins interact with several fungi including C. albicans, A. fumigatus, $H$. capsulatum, C. neoformans, P. marneffei and P. brasiliensis [95-101].

In animals infected with $P$. brasiliensis conidia, ECM proteins synthesis began with deposition of fibrin-like material as early as 2 days, and during the subsequent inflammatory periods studied. A normal expression and deposition of fibronectin and fibrinogen, but not of laminin, was also observed in the lungs of uninfected animals. In contrast, during the inflammatory process in infected animals, the lungs experienced reorganization with increased deposition of the three ECM proteins tested (Gonzalez et al., unpublished data). In addition, analysis by confocal laser scanning microscopic (CLSM) and phosphomolybdic acid-picrosirius red (PMA-PSR) stain in non-infected animals revealed a normal distribution of collagen and reticulin fibres in the lungs, while in the infected animals, these fibres fragmented during the first day post-infection, with an increase being noticed on the latter periods (Fig. 1g, h) (Gonzalez et al., unpublished data). The increase of ECM proteins was accompanied by a marked afflux of pro-inflammatory cells, suggesting their participation in the migration of such cells into the lung.

It is known that P. brasiliensis disseminates to several organs including liver, skin, spleen and lymph nodes. The manner in which the fungus gains access to these organs is unclear, but it may involve migration of $P$. brasiliensis-infected macrophages or dendritic cells [102]. In addition, degradation of ECM proteins may also play a role in this dissemination process, and it has also been demonstrated that $P$. brasiliensis is able to cleave type IV collagen, fibronectin and laminin through an exocellular serinethiol proteinase [103].

These ECM proteins also play another important role in the host-parasite interactions related to adhesion of micro-organisms to host tissues, a crucial first 
step in the establishment of infection and subsequent dissemination. This type of adhesion is mediated by specific fungal cell-surface components called adhesins, which frequently bind ECM proteins [104]. Recently, the presence of these adhesins on the surface of both $P$. brasiliensis conidia and yeast cells has been demonstrated [100, 101, 105]. The data described above strongly suggest that ECM proteins, especially fibronectin, fibrinogen, laminin and collagen appear to play a significant role in PCM pathogenesis.

Molecules participating in fungicidal mechanisms

Clearance of pathogens in the respiratory tract is mediated at least partly, by the synthesis and secretion of host defence molecules into the airway lumen. Thus, the phagocytic system constitutes an important effector mechanism of the natural and adaptative immune response leading to inhibition or destruction of several pathogens through the production of molecules that exert such effect, once they become activated by cytokines. Among these effector molecules, one can list degradative enzymes such as collagenases and elastases, lysozyme, defensins proteinases, reactive oxygen intermediates (ROI) and reactive nitrogen intermediates (RNI) [106-108].

Several investigators have shown that PMNs exert a fungicidal effect against $P$. brasiliensis yeasts, and that this effect is dependent on the respiratory burst products [109, 110]. In addition, it has been demonstrated that macrophages exert a fungicidal mechanism independent of oxidative burst products, but dependent on nitric oxide (NO) production [111, 112]. However, in vivo the role of these effector molecules against $P$. brasiliensis has not been elucidated.

\section{Expression of iNOS and nitric oxide production}

Nitric oxide (NO) is one the most important nitrogen intermediate; this molecule is generated by the oxidation of one of the nitrogen molecules of the aminoacid L-arginine [113-116]. NO is known to exert microbicidal effect against several micro-organisms [117].

In vitro, our group has shown that IFN- $\gamma$-activated peritoneal murine macrophages have a fungicidal effect against $P$. brasiliensis conidia, and that such effect depends on NO production [112]. This mechanism has been elucidated proposing that once in the cytoplasm, IFN- $\gamma$ attaches to its proper macrophage receptor inducing nuclear factor (NF)- $\kappa \mathrm{B}$ production, thus prompting expression of the inducible nitric oxide synthase (iNOS) with activation of the L-arginine-nitric oxide pathway, and subsequent NO production as early as 18-24 h post-challenge [118]. However, when macrophages were activated with TNF- $\alpha$, these cells exerted an antifungal activity independent of the NO pathway [119]. Recently, studies conducted in our laboratories demonstrated that the NO-mediated fungicidal mechanism exerted by IFN- $\gamma$-activated macrophages against $P$. brasiliensis conidia was dependent on an iron interaction [120]. In contrast, in vivo, we were unable to demonstrate $\mathrm{NO}$ production or iNOS mRNA expression during the early periods post-challenge (A. Gonzalez and M. Uran, unpublished data). Nonetheless, in other studies NO appears to play a dual role (in resistance and susceptibility) depending on the degree of expression [121, 122].

\section{Expression of lysozyme}

One of the most abundant antimicrobial proteins in the lungs is lysozyme [123]. This enzyme is a nonspecific antimicrobial protein, acting against both bacteria and fungi. Lysozyme released from alveolar macrophages is stimulated by exposure to particles, such as latex, zymosan and bacteria. After stimulation, rat alveolar macrophages contain 10-fold greater intracellular concentration of this enzyme, and release more lysozyme than rat blood PMNs [124]. Taking into account the above observations, lysozyme may represent a mechanism, by which alveolar macrophages contribute to pulmonary defence. In addition, recombinant TNF- $\alpha$ is known for its ability to stimulate lysozyme in human macrophages and for increasing the respiratory burst activity. As described above, our group has demonstrated that in the early stages post-infection of the conidia-induced murine PCM model, a high production of this cytokine was present in BAL fluids [29]. In addition, we have found that murine peritoneal macrophages, when activated with recombinant TNF- $\alpha$ exerted a fungicidal mechanism against P. brasiliensis conidia [119]. Furthermore, we observed an increase of lysozyme expression in the lungs of mice infected with $P$. brasiliensis conidia during the early stages of infection (1-4 days), with the expression 
concentrating mainly on PMNs and macrophages with a parallel decrease in the number of fungal propagules (Gonzalez et al., unpublished data). The microbicidal effect of lysozyme has been demonstrated against C. albicans and H. capsulatum $[106,125,126]$. These results suggest that in vivo, lysozyme could well be one of the molecules participating in the control of P. brasiliensis infection.

\section{Immune responses during the chronic stages of pulmonary infection with $P$. brasiliensis conidia}

PCM is considered as a chronic granulomatous progressive disease that affects predominantly the lungs with dissemination to other organs, thus becoming a systemic disease; in addition, this mycosis is characterized by a chronic immune response described for both human and experimental hosts [127].

Our mouse model of pulmonary PCM has also been used to study this chronic immune response; at this time, different immunological mechanisms occur in inflammatory responses, cytokine production, metalloproteinase expressions, nitric oxide participation, granuloma formation and, finally, in the chronic pulmonary sequelae characterized by fibrosis, as described below.

Presence of fungal cells in the lungs

As showed initially by McEwen et al. [15] and later by Franco et al. [61], the intranasal inoculation of $P$. brasiliensis conidia in $\mathrm{BALB} / \mathrm{c}$ male mice resulted in a progressive disease characterized by an increase

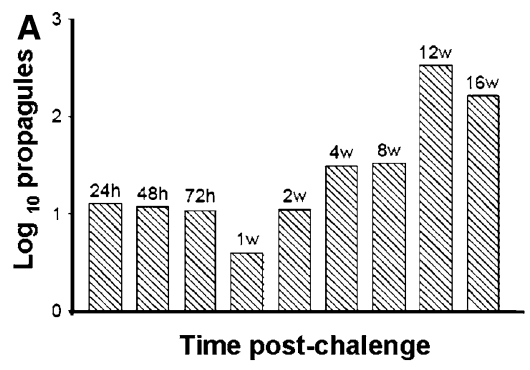

Fig. 2 Presence of fungal propagules in the lungs of $P$. brasiliensis conidia-infected mice. (a) Determination of P. brasiliensis propagules in lung tissues, according to time postchallenge. Adapted from Cock et al. [28]. (b) P. brasiliensis in the number of CFUs in the lungs during the course of infection (Fig. 2b). Later on, these findings were confirmed by the presence of yeast cells; quantification with a $40 \times$ objective of 10 microscopic fields, revealed that yeast cells were observed in increased numbers with time post-challenge (Fig. 2a) [28]. Extrapulmonary dissemination to the spleen (week 4) and liver (week 12) was shown by the isolation in culture of the fungus from these organs [15]. This progressive infection induced in the lungs, a chronic inflammatory response, as described below.

\section{Chronic inflammatory responses}

Histopathological studies of pulmonary tissues from conidia-infected animals showed a chronic inflammatory response with great flux of macrophages, lymphocytes, plasmocytes, multinucleated giant cells and PMNs in order of importance [15]; their migrations obeyed to the expression of certain cytokines (chemokines) and adhesion molecules produced in situ. After their migration to the pulmonary tissue, these cells centred around the fungus in special structures, granulomatas, characterizing this type of chronic diseases. The results showed that during chronic stages, the extension of the inflammatory infiltrate in the lungs occupied between $10.8 \pm 3.4 \%$ and $30.8 \pm 14.5 \%$ of this organ, with maximal values at 12 th week (Table 1) [28].

\section{Infiltrating cells}

We also determined the cellularity of bronchoalveolar lavages (BAL) in these infected mice, and

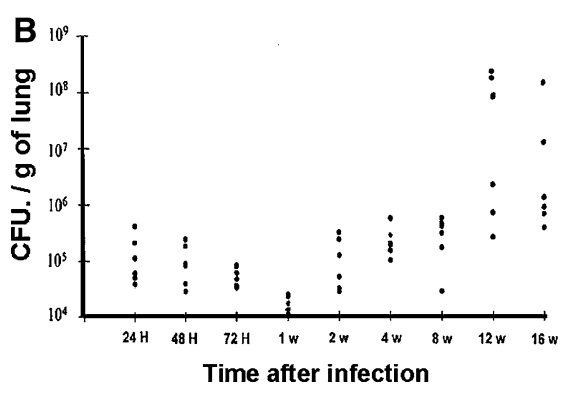

colony-forming units (C.F.U) recovered from pulmonary tissues (five individual counts). H: hours; w: weeks. Adapted from Franco et al. [61] 
Table 1 Extension of the inflammatory reaction according to time post-challenge (chronic stages)

\begin{tabular}{ll}
\hline $\begin{array}{l}\text { Time post-challenge } \\
(\text { weeks) }\end{array}$ & $\begin{array}{l}\text { Pulmonary involvement } \\
\text { percent } \pm \mathrm{SD}^{\mathrm{b}}\end{array}$ \\
\hline 8 & $10.8 \pm 3.4$ \\
12 & $30.8 \pm 14.5$ \\
16 & $15.8 \pm 11.3$ \\
\hline
\end{tabular}

${ }^{a}$ Each experimental group consisted of six animals

b The percentage was calculated by comparing control animals (no tissue reaction) to infected animals, and determining in the latter, the proportion of the lung showing inflammatory reaction (Adapted from Cock et al. [28])

observed values between 0.68 and $5.1 \times 10^{4}$ cells/ mouse, with $75-85 \%$ of these cells corresponding to macrophages, $15-20 \%$ to lymphocytes, $2-5 \%$ to PMNs; in addition, BALs showed increased numbers of giant cells [27]. Concerning type of cells present in the pulmonary infiltrate, mononuclear leukocytes increased and reached high, stable levels, above $82 \%$, in the chronic stages (8-16 weeks post-infection); conversely, PMNs decreased progressively in this period [28].

\section{Production of cytokines}

Cytokines are known to play a major role in a variety of immunological, inflammatory and infectious diseases [128]. In general, a clinical classification divides immunological cytokines into those that promote proliferation and functioning of type-1 helper T-cells (Th1 cells), e.g. IFN-gamma, and those which stimulate type-2 helper T-cells (Th2 cells), e.g. IL-4, IL-10, IL-13 and transforming growth factor (TGF-beta) [129].

During the chronic stages of experimental pulmonary PCM, cytokine productions has been studied in both lung homogenates and BAL supernatants by means of ELISA (protein) or RT-PCR (mRNA) assays.

In the lungs and with ELISA, infected mice exhibited significantly increased TGF- $\beta$ concentrations when compared with controls $(P=0.003)$ and at 8,12 and 16 weeks, TNF-alpha concentrations were lower than in earlier weeks, although they remained above control values $(P=0.0013)$ [61]. In addition, others cytokines tested, such as IFNgamma, IL-4 and IL-6 showed a significant increase in comparison with control, non-infected mice (Aristizabal et al., unpublished data). On the other hand, using the RT-PCR technique, we found that during the chronic stages, the mRNA for TNF- $\alpha$ and IL-10 were increased at 12 weeks, while the mRNA for GM-CSF was lower than in controls; concerning IFN- $\gamma$ and IL-12p40, there were no changes (Urán et al., unpublished data).

In other experimental model of PCM using susceptible and resistant mice, inoculated intratracheally with $P b$-yeast cells, it was observed that irrespective of the mouse strain, IFN-gamma plays a protective role with this cytokine being considered a major mediator of resistance against $P$. brasiliensis infection in mice [51]. Resistance to $P$. brasiliensis infection is linked preferentially to a Th1 immune response, whereas susceptibility is associated with absence of IFN-gamma production [130]. In the chronic phase of the disease, susceptible animals presented a transitory secretion of IL-2, and IL-4, and in the pulmonary infection, IL-4, IL-5 and IL-10 were preferentially detected in lung cells' washings of susceptible animals [62]. In addition, Arruda et al. [131], demonstrated a dual role for IL-4 in pulmonary paracoccidioidomycosis, as endogenous IL-4 could induce protection or exacerbation of the disease depending on the host genetic pattern. Other study showed that IL-12 protects mice against disseminated infection caused by $P$. brasiliensis, but enhances pulmonary inflammation [132].

It was also demonstrated that endogenous TNFalpha, acting through the p55 receptor, and IFNgamma, mediated resistance to $P$. brasiliensis infection [52]. In addition, IFN-gamma modulated the expression of chemokines and chemokine receptors, as well as the kind of cells that infiltrate the lungs of $P b$-infected mice [133].

\section{Expression of metalloproteinases and their inhibitors}

Matrix metalloproteinases (MMPs) are a family of zinc- and calcium-dependent, secreted or membraneanchored endopeptidases, which comprise 22 different members. Although they exhibit a broad substrate spectrum, they are subdivided according to their main substrate into collagenases, gelatinases, stromelysins, matrilysins, metalloelastase, membrane-type MMPs (MT-MMPs) and others. MMPs 


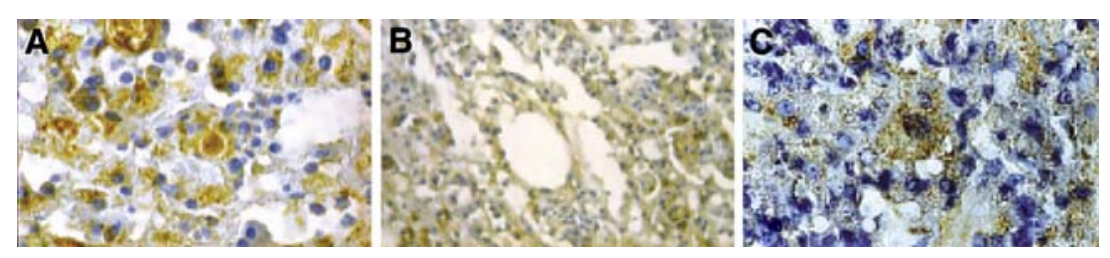

Fig. 3 Expression of MMP-1 (a), MMP-2 (b) and TIMP-1 (c), in the lungs of P. brasiliensis conidia-infected animals, during the chronic periods post-infection, and using an immunohistochemical technique (Adapted from Bárcenas et al. [135])

are secreted as zymogens and become activated by cleavage of their propeptide [134]. MMPs and their specific inhibitors, TIMPs (tissue inhibitors of metalloproteinases), are involved in many physiological processes, also taking part in the pathophysiologic mechanisms responsible for a wide range of diseases. Thus, MMPs and TIMPs are involved in both fibrogenesis and fibrolysis process.

In order to determine the participation of these molecules during the pulmonary fibrous process induced in BALB/c mice inoculated i.n. with $P$. brasiliensis conidia, we studied the expression of interstitial colagenase (MMP-1), gelatinase A (MMP2) and TIMP-1 in pulmonary tissue of infected animals, during different periods post-infection and using an immunohistochemical technique (Fig. 3). The results showed that after 4 weeks post-inoculation, $85.7 \%$ of infected mice expressed MMP-1 and MMP-2, and 71.4\% TIMP-1, all with moderate intensity in alveolar macrophages around peribronchial tissues and blood vessels' smooth muscle cells. At 16 weeks postinfection, practically all infected biopsies showed moderate staining to metalloproteinases, but with higher intensity in $30 \%$ samples, especially in those representing epithelial and macrophagic cells [135].

In conclusion, these results suggest that as more collagen becomes deposited, more metalloproteinases and tissular inhibitors will be present conforming an inflammatory pattern in both production and depot. Alveolar macrophages and interstitial cells are the principal MMP-1, MMP-2 and TIMP-1 production sources [135].

\section{Granuloma formation}

Direct evidences indicate that granuloma formation as induced by $P$. brasiliensis infection is intimately related to the host's immune response. In PCM, the formation of granuloma and the efficient control of fungal proliferation in their interior, are in favour of the cellular immune response role [136].

Experimentally-induced granulomas appear identical to those seen in human paracoccidioidomycosis [61]. This structure becomes apparent only during the first week post-challenge, and their number increases with time post-infection, so that by $4-8$ weeks after challenge, $58 \%$ of the animals exhibit well-formed epithelioid granulomas with a PMN component, especially at the perivascular level and also, with persistence of the lympho-plasmocytic infiltrates [27, 28] (Fig. 4). During the following weeks and in the whole lung, granulomas vary in number from 8 to 16 weeks, with a peak at week 12. Granulomas are compact when first formed, but become loose, fusing with each other, with the progression of the infection. Yeast cells are numerous, in active multiplication,

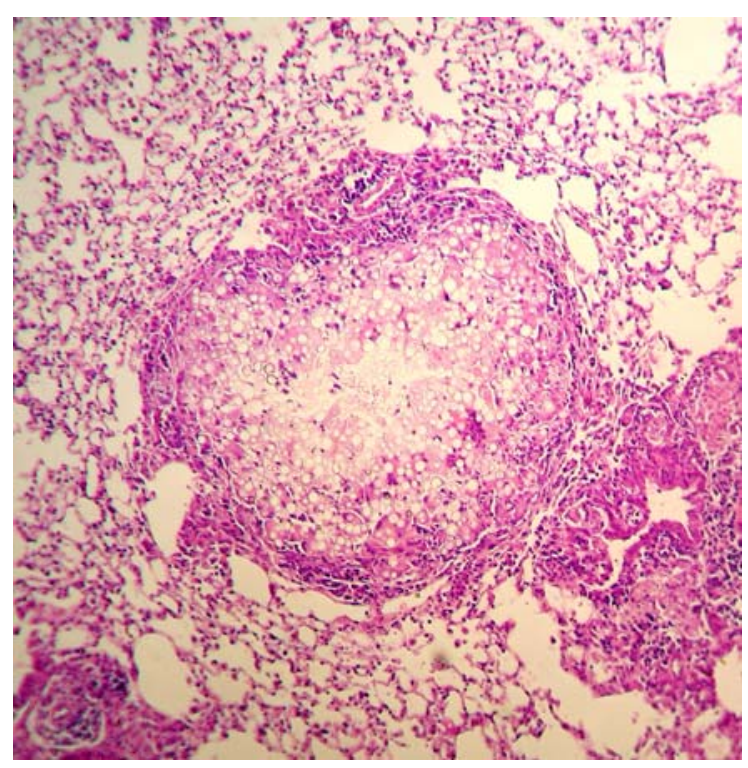

Fig. 4 Histological aspect of a granuloma in lung tissues from mice, 12 weeks post-inoculation with P. brasiliensis viable conidia. H\&E 
and appear intermingled with PMNs, plasmocytes and fibroblasts [28].

Other authors, using a different experimental PCM model (C57 BL/6 mice infected via trachea with $1 \times 10^{6}$ viable yeast cells of $\mathrm{Pb} 18$ ), have demonstrated that the organization of a granulomatous reaction in ICAM-1 deficient mice is delayed, starting only on day 60 after infection, whereas in wild-type mice, this process was completed on day 30 postinfection. These data show that ICAM-1 is effectively involved in cellular migration and in the organization of the granulomatous lesion caused by the fungus $P$. brasiliensis [137]. Moreover, the absence of ICAM-1 resulted in high susceptibility to the infection, in increased growth and dissemination of fungus, decreased number of $\mathrm{CD} 3+\mathrm{CD} 4+$ and $\mathrm{CD} 3+\mathrm{CD} 8+\mathrm{T}$ cells and increased production of interleukin- 4 at the inflammatory site.

Fibrosis development

Fibrosis is a frequent and incapacitating sequelae of numerous infections [127, 138, 139], immune diseases [140] and exposure to toxic drugs [141]. It may also be the result of cryptogenic processes [142-144]. In these diseases, fibrosis shares common characteristics, including fibroblast proliferation and extracellular matrix deposition [145-147]. Lung fibrosis often follows a series of chronic granulomatous processes. Frequently, fibrosis begins with inflammation and leukocyte infiltration, followed by increased cytokine generation [143-145]. These reactions are thought to promote excess accumulation of connective tissue, which usually results in structural and functional alteration of the involved tissues [145]. Fibrosis appears to begin simultaneously with both the inflammatory process and the presence of leukocyte infiltrates; it then progresses and consolidates at the time of granuloma formation. Based largely on in vitro experiments, transforming growth factor- $\beta$ (TGF- $\beta$ ), tumour necrosis factor- $\alpha$ (TNF- $\alpha$ ), interleukin-1 (IL-1), IL-6 and IL-13 have all been implicated in the generation of fibrosis [148].

In our mouse model, induced by the i.n. inoculation of $P$. brasiliensis conidia, we observed that after 4 weeks, the lungs showed disorganized and disrupted reticular fibres. Six to eight weeks later, peribronchial infiltrates were larger and appeared surrounded by reticular fibres; thick collagen I fibres were noticed in the infiltrated areas at this time. On weeks 10-12, infiltrates were confluent and reticular fibres were concentrated around the inflammatory foci; collagenization was apparent. Observations up to 16 weeks revealed diffuse involvement of the lung parenchyma with extensive collagenization [27] (Fig. 5).

Another parameter indicative of fibrosis is the hydroxyproline concentration; we measured this compound in pulmonary tissues from control and infected mice. The results showed that in comparison with noninfected controls, infected mice had increased concentrations of hydroxyproline by 8 weeks post-challenge, $(P=0.0237)$. Mice at weeks 8,12 and 16 had much higher hydroxyproline concentrations than mice at 1,2 and 4 weeks $(P=0.006)$. At weeks 12 and 16 , the concentrations of hydroxyproline were 3.6 and 8.6 times higher than in control animals of the same age [61].

Fibrosis was associated with formation of granulomas, increase in lung hydroxyproline and sustained increases in tissue tumour necrosis factor- $\alpha$ and transforming growth factor- $\beta$; suggesting a role for these cytokines in generation of pulmonary fibrosis associated with chronic granulomatous infectious diseases [61].

Latter on, we studied the contribution of viable and non-viable P. brasiliensis propagules to the

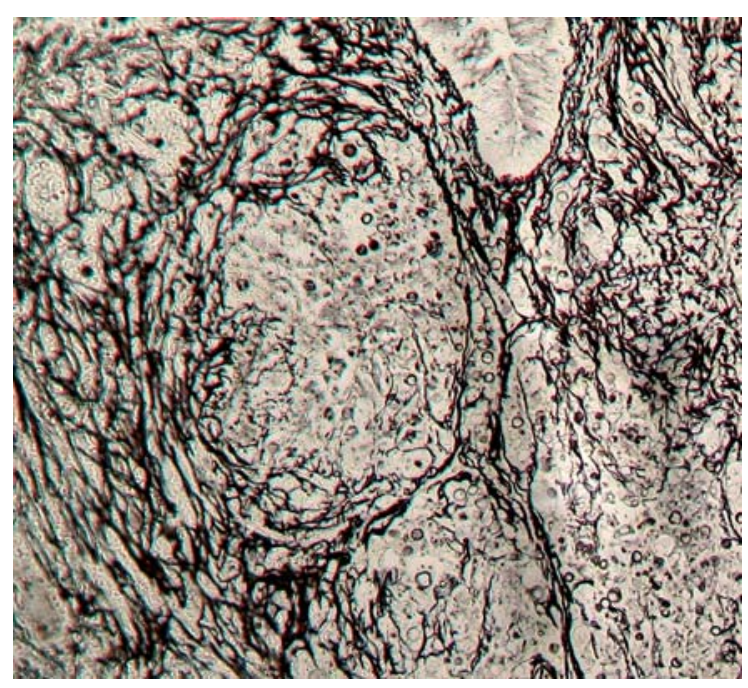

Fig. 5 Thick and disorganized reticulin fibres in mice lung tissues after 12 weeks post-inoculation with P. brasiliensis viable conidia. Gomori stain 
development of fibrosis. BALB/c male mice, 4-6 weeks old, were inoculated intranasally either with $4 \times 10^{6}$ viable conidia (Group I) or $6.5 \times 10^{6}$ fragmented yeast cells (Group II). Results indicated that tissue response to fragmented yeast cells was transitory, while viable conidia evoked a progressive inflammatory reaction leading to granuloma formation and to excess production and/or disarrangement of collagens I and III; the latter led to fibrosis [28].

Much remains to be done before the genesis of the fibrotic process in paracoccidioidomycosis is understood; however, the possibility offered by the mouse model reported here may contribute to designing new, more far reaching experiments.

\section{iNOS expression and nitric oxide (NO) participation}

In order to determine if the NO system had a role during the chronic immune response in our PCM pulmonary model, we developed an immunohistochemical study for iNOS (NOS2) detection on lung biopsies from infected mice. We observed that this enzyme was expressed mainly in vivo in the epithelioid histiocytes, and that its maximal expression occurred 12 weeks after infection $(P<0.01)$. Expression of iNOS correlated significantly $(r=$ 0.77891 ) with the number of granulomas present in the pulmonary parenquima, suggesting that iNOS induction at this stage, would depend on factors or mechanisms related to the environment in the granuloma (Caro et al., unpublished data). This association has been reported previously in other experimentally induced models of granulomatous reaction with endotoxin [149], Leishmania major [150] and C. neoformans [151].

In addition, in order to study the in vivo participation of $\mathrm{NO}$ in our murine model, we selected aminoguanidin (AG) as a highly specific inhibitor of iNOS [152]. We treated groups ( $n=21$ for each one) of infected and non-infected mice with AG $1 \%$ in the drinking water, ad libitum [152-155]; another two groups (same number of mice) of infected and noninfected mice were treated with PBS; all the animals were observed daily for 190 days, the deaths were recorded, and the survival time was calculated. We found that, at day $141,90 \%$ of P. brasiliensisinfected, AG-treated mice had died in contrast with
$40 \%$ of the $P$. brasiliensis-infected PBS-treated mice $(P=0.00778)$. Treatment with AG $1 \%$ at lib was non-toxic $(90.5 \%$ survival in the non-infected AG-treated mice). These results suggest that during the 12-17 weeks of infection, the NO system played an important protecting role against fungal infection (Urán et al., unpublished data). This effect has been observed in other experimental models, Beckerman et al. [156] working with listeriosis demonstrated that the administration ad lib of AG resulted in high mortality and greater bacterial loads in the spleen. Similar results were observed in a model of latent tuberculosis [155].

However, the in vivo role of $\mathrm{NO}$ in experimental PCM is very controversial; although NO is important for the killing of fungi, the activation of $\mathrm{NO}$ production in P. brasiliensis infection contributes to the occurrence of the immunosuppression observed during the course of the infection [121]. Nascimento et al. [122] proposed a dual role for nitric oxide in experimental PCM: NOS2-derived NO is essential for resistance to paracoccidioidomycosis, but its overproduction is associated with susceptibility.

\section{Concluding remarks}

The body of information just presented on the host$P$. brasiliensis conidia interactions is, undoubtedly, of importance as it reproduces those initial stages of human paracoccidioidomycosis, which are not easily recognized in patients. The way is now open to valuable comparisons with experimental models using yeast cells as the inoculum so as to determine if the initial encounter with the naturally infecting particle does, indeed, marks a difference in the host response, and in the overall course of the mycosis. Additionally, a concerted effort has been made to appraise the whole gamut of immune factors and related molecules that directly or indirectly, contribute to shape the pathogenesis of this Latin American mycosis, including the most feared of its sequelae, fibrosis. It is expected that this review will contribute to a better understanding of paracoccidioidomycosis, so that future patients may benefit from recently acquired knowledge.

Acknowledgements The authors would like to recognize the work of many physicians, microbiologists, medical and 
paramedical students and laboratorians, who, for many years, contributed to the development of the studies reported here. Many should be cited, but the following deserve especial recognition: Drs. Henrique Lenzi, Elmer Brummer, David A. Stevens, Karl A. Clemons, John R. Graybill, Andrew Hamilton, Juan G. McEwen, Susana Restrepo, Angela Tobón, Ana María Cock, Claudia Bárcenas, Liliana Franco, Camilo Roldán, Ana C. Ruiz, Beatriz E. Aristizábal, Beatriz L. Gómez, Soraya Diez, Erika Caro, Martha E. Urán, Judith Trujillo, Myrtha Arango, Catalina de Bedout, Angela Tabares, Jorge Sahaza, Diana Vélez, Blanca L. Ortiz y María Elena Salazar. We would also like to express our appreciation to the following institutions: Instituto Colombiano para el Desarrollo de la Ciencia y la Tecnología Francisco José de Caldas (COLCIENCIAS), Fundación para la Promoción de la Investigación y la Tecnología del Banco de la República, Bogotá, Colombia. CODI of Universidad de Antioquia, Corporación para Investigaciones Biológicas (CIB), Medellín, Colombia and to the Welcome Trust, London, UK, for their financial support.

\section{References}

1. Beaman L, Pappagianis D, Benjamini E. Significance of $\mathrm{T}$ cells in resistance to experimental murine coccidioidomycosis. Infect Immun 1977;17:580-5.

2. Morozumi PA, Brummer E, Stevens DA. Protection against pulmonary blastomycosis: correlation with cellular and humoral immunity in mice after subcutaneous nonlethal infection. Infect Immun 1982;37:670-8.

3. Nickerson DA, Havens RA, Bullock WE. Immunoregulation in disseminated histoplasmosis: characterization of splenic suppressor cell populations. Cell Immunol 1981; 60:287-97.

4. Iabuki K, Montenegro MR. Experimental paracoccidioidomycosis in the Syrian hamster: morphology, ultrastructure and correlation of lesions with presence of specific antigens and serum levels of antibodies. Mycopathologia 1979;67:131-41.

5. Peracoli MTS, Mota NGS, Montenegro MR. Experimental paracoccidioidomycosis in the Syrian hamster. Morphology and correlation of lesions with humoral and cell mediated immunity. Mycopathologia 1982;79:7-17.

6. Brummer E, Restrepo A, Stevens DA, Azzi R, Gomez AG, Hoyos G, McEwen JG, Cano LE, de Bedoout C. Murine model of paracoccidioidomycosis production of fatal acute pulmonary or chronic pulmonary and disseminated disease. Immunological and pathological observations. J Exp Pathol 1984;1:241-55.

7. Defaveri J, Rexkallah-Iwasso MT, Franco MF. Experimental pulmonary paracoccidioidomycosis in mice: morphology and correlation of lesions with humoral and cellular immune response. Mycophatologia 1982;77: 3-11.

8. Moscardi M, Franco MF. Paracoccidioidomicose experimental do camundongo. I. Aspectos immunopatologicos da infeccao intraperitoneal. Rev Inst Med Trop Sao Paulo 1980;22:286-93.
9. Moscardi M, Franco MF. Paracoccidioidomicose experimental do camundongo. 1I. Infeccao intraperitoneal após sensibilizacao previa. Rev Inst Med Trop Sao Paulo 1981;23:204-11.

10. De Brito T, Fava-Netto C. Disseminated experimental South American blastomycosis of the guinea pig. A pathologic and immunologic study. Pathol Microbiol 1963;26:29-43.

11. Fava-Netto C, De Brito T, Lacaz CS. Experimental South American blastomycosis of the guinea pig. Pathol Microbiol 1961;24:192-206.

12. Greer DL, McMurray DN. Pathogenesis and immune response to Paracoccidioides brasiliensis in the fructivorous bat, Artibeus lituratus. Sabouraudia 1981;19: 165-78.

13. Eisele RC, Juliani LC, Belitardo DR, Itano EN, Estevao $\mathrm{D}$, Bracarense AP, Camargo ZP, Ono MA. Immune response in dogs experimentally infected with Paracoccidioides brasiliensis. Med Mycol 2004;42:549-53.

14. Gesztesi JL, Dias MA, de Souza AR, de Almeida SR, Lopes JD, Mariano M. Subcutaneous infection of mice with Paracoccidioides brasiliensis induces a peculiar pattern of inflammatory and immune responses. Mycopathologia 1999;145:7-14.

15. McEwen JG, Bedoya V, Patiño MM, Salazar ME, Restrepo A. Experimental murine paracoccidioidomycosis induced by the inhalation of conidia. J Med Vet Mycol 1987;25:165-75.

16. Kashino SS, Fazioli Rdos A, Moscardi-Bacchi M, Franco M, Singer-Vermes LM, Burger E, Calich VLG. Effect of macrophage blockade on the resistance of inbred mice to Paracoccidioides brasiliensis infection. Mycopathologia 1995;130:131-40.

17. Arruda MS, Coelho KI, Montenegro MR. Experimental paracoccidioidomycosis of hamster inoculated in the cheek pouch. Mycopathologia 1994;128:67-73.

18. Franco M, Mendez RP, Dillon NL, Mota NGS. Paracoccidioidomycosis: a recently proposed classification of its clinical forms. Rev Soc Bras Med Trop 1987;20:129_ 32.

19. Zacharias D, Ueda A, Moscardi-Bacchi M, Franco M, SanBlas G. A comparative histopathological, immunological, and biochemical study of experimental intravenous paracoccidioidomycosis induced in mice by three Paracoccidioides brasiliensis isolates. J Med Vet Mycol 1986;24:445-54.

20. Roldán CJ, Tabares AM, Gómez BL, Aristizábal BE, Cock AM, Restrepo A. The oral route in the pathogenesis of paracoccidioidomycosis: an experimental study in $\mathrm{BALB} / \mathrm{c}$ mice infected with $P$. brasiliensis conidia. Mycopathologia 2001;151(2):57-62.

21. Bedoya V, McEwen JG, Tabares AG, Uribe F, Restrepo A. The pathogenesis of paracoccidioidomycosis. A histophatological study of the experimental murine infection. Mycopathologia 1986;94:133-44.

22. Moscardi M, Franco MF. Experimental paracoccidioidomycosis in the mouse III Histophatological and immunological findings after intravenous infection in the presence or absence of previous immunization. Rev Soc Bras Med Trop 1985;18:101-8. 
23. Robledo MA, Graybill JR, Ahrens J, Restrepo A, Drutz DJ, Robledo M. Host defence against experimental paracoccidioidomycosis. Am Rev Resp Dis 1982;125:563-7.

24. Calich VLG, Singer-Vermes LM, Siqueira AM, Burger E. Susceptibility and resistance of inbred mice to Paracoccidioides brasiliensis. Br J Exp Pathol 1985;66:585-94.

25. Restrepo A, McEwen JG, Castañada E. The habitat of Paracoccidioides brasiliensis: how far from solving the riddle? Med Mycol 2001;39:232-41.

26. Restrepo A. The ecology of Paracoccidioides brasiliensis: a puzzle still unsolved. J Med Vet Mycol 1985; 23:323-34.

27. Restrepo S, Tobon A, Trujillo J, Restrepo A. Development of pulmonary fibrosis in mice during infection with Paracoccidioides brasiliensis conidia. J Med Vet Mycol 1992;30(3):173-84.

28. Cock AM, Cano LE, Vélez D, Aristizábal BH, Trujillo J, Restrepo A. Fibrotic sequelae in pulmonary paracoccidioidomycosis: histopathological aspects in BALB/c mice infected with viable and non-viable Paracoccidioides brasiliensis propagules. Rev Inst Med Trop Sao Paulo 2000;42:59-66.

29. González A, Sahaza JH, Ortiz BL, Restrepo A, Cano LE. Production of pro-inflammatory cytokines during the early stages of experimental Paracoccidioides brasiliensis infection. Med Mycol 2003;41:391-9.

30. González A, Lenzi HL, Motta EM, Sahaza JH, Cock AM, Ruiz AC, Restrepo A, Cano LE. Expression of adhesión molecules in lungs of infected mice with Paracoccidioides brasiliensis conidia. Microbes Infect 2005;7:666-73.

31. de Brito T, Franco MF. Granulomatous inflammation. Rev Inst Med Trop Sao Paulo 1994;36(2):185-92.

32. Kerr IB, Araripe JR, Oliveira PC, Lenzi HL. Paracoccidioidomycosis: a sequential histopathologic study of lesions in experimentally-infected rats. Rev Inst Med Trop Sao Paulo 1988;30(5):336-50.

33. Burger E, Miyaji M, Sano A, Calich VL, Nishimura K, Lenzi HL. Histopathology of paracoccidioidomycotic infection in athymic and euthymic mice: a sequential study. Am J Trop Med Hyg 1996;55(2):235-42.

34. Xidieh CF, Lenzi HL, Calich VL, Burger E. Influence of the genetic background on the pattern of lesions developed by resistant and susceptible mice infected with Paracoccidioides brasiliensis. Med Microbiol Immunol 1999;188:41-9.

35. Dinarello CA. Interleukin-1 and its biologically related cytokines. Adv Immunol 1989;44:153-205.

36. Louie A, Baltch AL, Smith RP, Franke MA, Ritz WJ, Singh JK, Gordon MA. Tumor necrosis factor alpha has a protective role in murine model of systemic candidiasis. Infect Immun 1994;62:2761-72.

37. Smith JG, Magee DM, Williams DM, Graybill JR. Tumor necrosis factor-a plays a role in host defense against Histoplasma capsulatum. J Infect Dis 1990;162:1349-53.

38. Tracey KJ, Cerami A. Tumor necrosis factor: a pleiotropic cytokine and therapeutic target. Ann Rev Med 1994;45:491-503.

39. Tracey KJ. Tumor necrosis factor-alpha (TNF- $\alpha)$. In: Thompson A, editor. The cytokine handbook. London: Academy Press; 1994. p. 289-304.
40. Cassatella MA. The production of cytokines by polymorphonuclear neutrophils. Immunol Today 1995;16: 21-7.

41. Vadas MA, David JR, Butterworth A, Pisani NT, Siongok TA. A new method for the purification of human eosinophils and neutrophils and a comparison of the ability of these cells to damage schistosomula of Schistosoma mansoni. J Immunol 1979;122:1228-36.

42. Kephart GM, Andrade ZA, Gleich GJ. Localization of eosinophil major basic protein onto eggs of Schistosoma mansoni in human pathologic tissue. Am $\mathrm{J}$ Pathol 1988;133:389-96.

43. Kephart GM, Gleich GJ, Connor DH, Gibson DW, Ackerman SJ. Deposition of eosinophil granule major basic protein onto microfilariae of Onchocerca volvulus in the skin of patients treated with diethylcarbamazine. Lab Invest 1984;50:51-61.

44. Wassom DL, Gleich GJ. Damage to Trichinella spiralis newborn larvae by eosinophil major basic protein. Am J Trop Med Hyg 1979;28:860-3.

45. Molina HA, Kierszenbaum F, Hamann K, Gleich GJ. Toxic effects produced or mediated by human eosinophil granule components on Trypanosoma cruzi. Am J Trop Med Hyg 1988;38:327-34.

46. Molina HA, Kierszenbaum F. Interaction of human eosinophils or neutrophils with Trypanosoma cruzi in vitro causes bystander cardiac cell damage. Immunology 1989;66:289-95.

47. Wagner JM, Franco M, Kephart GM, Gleich GJ. Localization of eosinophil granule major basic protein in paracoccidioidomycosis lesions. Am J Trop Med Hyg 1998;59:66-72.

48. Bancroft GL, Schreiber RD, Unanue ER. Natural immunity: a $\mathrm{T}$ cell independent pathway of macrophage activation, defined in scid mice. Immunol Rev 1991; 124:5-24.

49. Fong TA, Mosmman TR. Allo-reactive murine CD8 T cell clones secrete the Th1 pattern of cytokines. J Immunol 1990;144:1744-52.

50. Mossman TR, Cherwinski H, Bond MW, Giedlin MA, Coffman RL. Two types of murine helper T clones. I. Definition according to profiles of lymphokines activities and secreted proteins. J Immunol 1986;136:2348-57.

51. Cano LE, Kashino SS, Arruda C, Andre D, Xidieh CF, Singer-Vermes LM, Vaz CA, Burger E, Calich VLG. Protective role of gamma interferon in experimental pulmonary paracoccidioidomycosis. Infect Immune 1998; 66:800-6.

52. Souto JT, Figueriedo F, Furlanetto A, Pfeffer K, Rossi MA, Silva JS. Interferon-gamma and tumor necrosis factor-alpha determine resistance to Paracoccidioides brasiliensis infection mice. Am J Pathol 2000;156:181120.

53. Cano LE, Singer-Vermes LM, Mengel JA, Xidieh CF, Arruda C, André DC, Vaz CAC, Burger E, Calich VLG. Depletion of CD8 T cells in vivo impairs host defense of resistance and susceptible mice to pulmonary paracoccidioidomycosis. Infect Immun 2000;68:352-9.

54. Peracoli MT, Fortes MR, Da Silva MF, Montenegro MR. Natural killer cell activity in experimental 
paracoccidioidomycosis of the Syrian hamster. Rev Inst Med Trop Sao Paulo 1995;37:129-36.

55. Pina A, Valente-Ferrerira RC, Molinari-Madlum EEW, Vaz CAC, Keller AC, Calich VLG. Absence of interleukine-4 determines less severe pulmonary paracoccidioidomycosis associated with impaired Th2 response. Infect Immun 2004;72:2369-78.

56. Kullberg BJ, Netea MG, Vonk AG, Van der Meer JW. Modulation of neutrophil function in host defense against disseminated Candida albicans infection in mice. FEMS Immunol Med Microbiol 1999;26:299-307.

57. Netea MG, Van Tits LJ, Curfs JH, Amiot F, Meis JF, van der Meer JW, Kullberg BJ. Increased susceptibility of TNF- $\alpha$ lymphotoxin-alpha double knockout mice to systemic candidiasis through impaired recruitment of neutrophils and phagocytosis of Candida albicans. J Immunol 1999;163:1498-505.

58. Schelenz S, Smith DA, Bancroft GT. Cytokine and chemokine responses following pulmonary challenge with Aspergillus fumigatus: obligatory role of TNF-alpha and GM-CSF in neutrophil recruitment. Med Mycol 1999; 37:183-94.

59. Chen W, Havell EA, Moldawer LL, McIntyre KW, Chizzonite RA, Harmsen AG. Interleukin-1: an important mediator of host resistance against Pneumocystis carinii. J Exp Med 1992;176:713-8.

60. Cano LE, Singer-Vermes LM, Vaz CAC, Russo M, Calich VLG. Pulmonary paracoccidioidomycosis in resistant and susceptible mice: relationship among progression of infection, bronchoalveolar cell activation, cellular immune response, and specific isotype patterns. Infect Immun 1995;63:1777-83.

61. Franco L, Najvar L, Gómez B, Restrepo S, Graybill JR, Restrepo A. Experimental pulmonary fibrosis induced by Paracoccidioides brasiliensis conidia: measurement of the host local responses. Am J Trop Med Hyg 1998; 58:424-30.

62. Calich VL, Kashino SS. Cytokines produced by susceptible and resistant mice in the course of Paracoccidioides brasiliensis infection. Braz J Med Biol Res 1998;31: 615-23.

63. Kurita N, Biswas SK, Oarada M, Sano A, Nishimura K, Miyaji M. Fungistatic and fungicidal activities of murine polymorphonuclear leukocytes against yeast cells of Paracoccidioides brasiliensis. Med Mycol 1999;37:19-24.

64. Kurita N, Oarada M, Ito E, Miyaji M. Antifungal activity of human polymorphonuclear leukocytes against yeast cells of Paracoccidioides brasiliensis. Med Mycol 1999; 37:261-7.

65. Kurita N, Oarada M, Miyaji M, Ito E. Effect of cytokines on antifungal activity of human polymorphonuclear leukocytes against yeast cells of Paracoccidioides brasiliensis. Med Mycol 2000;38:177-82.

66. Van Enckevort FH, Netea MG, Hermus AR, Sweep CG, Meis JF, Van der Meer JW, Kullberg BJ. Increased susceptibility to systemic candidiasis in interleukin-6 deficient mice. Med Mycol 1999;37(6):419-26.

67. Taramelli D, Malabarba MG, Sala G, Basilico N, Cocuzza G. Production of cytokines by alveolar and peritoneal macrophages stimulated by Aspergillus fumigatus conidia or hyphae. J Med Vet Mycol 1996;34(1):49-56.
68. Retini C, Vecchiarelli A, Monari C, Tascini C, Bistoni F, Kozel TR. Capsular polysaccharide of Cryptococcus neoformans induces proinflammatory cytokine release by human neutrophils. Infect Immun 1996;64(8):2897-903.

69. Cox RA, Magee DM. Production of tumor necrosis factor alpha, interleukin-1 alpha, and interleukin-6 during murine coccidioidomycosis. Infect Immun 1995;63(10): 4178-80.

70. Bevilacqua MP, Nelson RM. Selectins. J Clin Invest 1993;91:379-87.

71. Springer TA. Traffic signals for lymphocytes recirculation and leukocytes emigration: the multistep paradigm. Cell 1994;76:301-14.

72. Bohnet S, Braun J, Dalhoff K. Intercellular adhesion molecule-1 (ICAM-1) is upregulated on alveolar macrophages from AIDS patients. Eur Respir J 1994;7(2): 229-34.

73. Dalhoff K, Bohnet S, Braun J, Kreft B, Wiessmann KJ. Intercellular adhesion molecule 1 (ICAM-1) in the pathogenesis of mononuclear cell alveolitis in pulmonary sarcoidosis. Thorax 1993;48(11):1140-4.

74. Pilewski JM, Albelda SM. Adhesion molecules in the lung. An overview. Am Rev Respir Dis 1993;148(6 Pt 2):S31-7.

75. Resnick MB, Weller PF. Mechanisms of eosinophil recruitment. Am J Respir Cell Mol Biol 1993;8(4): 349-55.

76. Hamacher J, Schaberg T. Adhesion molecules in lung diseases. Lung 1994;172(4):189-213.

77. Wegner CD, Gundel RH, Reilly P, Haynes N, Letts LG, Rothlein R. Intercellular adhesion molecule-1 (ICAM-1) in the pathogenesis of asthma. Science 1990;247(4941): 456-9.

78. Shijubo N, Imai K, Nakanishi F, Yachi A, Abe S. Elevated concentrations of circulating ICAM-1 in far advanced and miliary tuberculosis. Am Rev Respir Dis 1993;148(5):1298-301.

79. Izzo AA, Lovchik JA, Lipscomb MF. T and B cell independence of endothelial cell adhesion molecule expression in pulmonary granulomatous inflammation. Am J Respir Cell Mol Biol 1998;19(4):588-97.

80. Yu ML, Limper AH. Pneumocystis carinii induces ICAM-1 expression in lung epithelial cells through a TNF-alpha-mediated mechanism. Am J Physiol 1997;273(6 Pt 1):L1103-11.

81. Chu HW, Wang JM, Boutet M, Boulet LP, Laviolette M. Increased expression of intercellular adhesion molecule-1 (ICAM-1) in a murine model of pulmonary eosinophilia and high IgE level. Clin Exp Immunol 1995;100(2): 319-24.

82. Yokomura I, Iwasaki Y, Nagata K, Nakanishi M, Natsuhara A, Harada H, Kubota Y, Ueda M, Inaba T, Nakagawa M. Role of intercellular adhesion molecule 1 in acute lung injury induced by candidemia. Exp Lung Res 2001;27(5):417-31.

83. Davis SL, Hawkins EP, Mason EO, Smith CW, Kaplan SL. Host defenses against disseminated candidiasis are impaired in intercellular adhesion molecule 1-deficient mice. J Infect Dis 1996;174(2):435-9.

84. Albeda SM, Smith CW, Ward PA. Adhesion molecules and inflammatory injury. FASEB J 1994;8:504-12. 
85. Osborn L, Hession C, Tizard R, Vasallo C, Luhowsky S, Chi-Rosso G, Lobb R. Direct expression of vascular cell adhesion molecule-1, a cytokine-induced endothelial protein that binds to lymphocytes. Cell 1989;59:1203-11.

86. Carlos TM, Harlan JM. Membrane proteins involved in phagocyte adherence to endothelium. Immunol Rev 1990, 114:5-27.

87. Masinovsky B, Urdal D, Gallatin WM. IL-4 acts synergistically with IL-1 beta to promote lymphocyte adhesion to microvascular endothelium by induction of vascular cell adhesion molecule-1. J Immunol 1990;145:2886-95.

88. Rice GE, Munro JM, Bevilacqua MP. Inducible cell adhesion molecule 110 (INCAM-110) is an endothelial receptor for lymphocytes. A CD11/CD18-independent adhesion mechanism. J Exp Med 1990;171:1369-74.

89. Rice GE, Munro JM, Corless C, Bevilacqua MP. Vascular and nonvascular expression of INCAM-110. A target for mononuclear leukocyte adhesion in normal an inflamed human tissues. Am J Pathol 1991;138:385-93.

90. Hemler ME, Elices MJ, Parker C, Takada Y. Structure of the integrine VLA-4 and its cell-cell and cell-matrix adhesion. Immunol Rev 1990;114:45-65.

91. Fornazim MC, Balthazar A, Quagliato R, Mamoni RL, Garcia C, Blotta MHSL. Evaluation of bronchoalveolar cells in pulmonary paracoccidioidomycosis. Eur Respir J 2003;22:895-9.

92. Roche WR, Beasley R, Williams JH, Holgate ST. Subepithelial fibrosis in the bronchi of asthmatics. Lancet 1989;1:520-4.

93. Chu HW, Halliday JL, Martin RJ, Leung DY, Szefler SJ, Wenzel SE. Collagen deposition in large airways may not differentiate severe asthma from milder forms of the disease. Am J Respir Crit Care Med 1998;158:1936-44.

94. Huang J, Oliveinstein R, Taha R, Hamid Q, Ludwig M. Enhanced proteoglycans deposition in the airway wall of atopic asthmatics. Am J Respir Crit Care Med 1999; 160:725-9.

95. Gaur NK, Klotz SA, Henderson RL. Overexpression of the Candida albicans ALA1 gene in Saccharomyces cerevisiae results in aggregation following attachment of yeast cells to extracellular matrix proteins, adherence properties similar to those of Candida albicans. Infect Immun 1999;67:6040-7.

96. Wasylnka JA, Moore MM. Adhesion of Aspergillus species to extracellular matrix proteins: evidence for involvement of negatively charged carbohydrates on the conidial surface. Infect Immun 2000;68:3377-84.

97. McMahon JP, Wheat J, Sobel ME, Pasula R, Downing JF, Martín WJ. Murine laminin binds to Histoplasma capsulatum. A possible mechanism of dissemination. J Clin Invest 1995;96:1010-7.

98. Rodrigues ML, Dos Reis G, Puccia R, Travassos LR, Alviano CS. Cleavage of human fibronectin and other basement membrane-associated proteins by a Cryptococcus neoformans serine proteinase. Microb Pathog 2003;34:65-71.

99. Hamilton AJ, Jeavons L, Youngchim S, Vanittanakom N. Recognition of fibronectin by Penicillium marneffei conidia via a sialic acid-dependent process and its relationship to the interaction between conidia and laminin. Infect Immun 1999;67:5200-5.
100. Gonzalez A, Gomez BL, Restrepo A, Hamilton JA, Cano LE. Recognition of extracellular matrix proteins by Paracoccidioides brasiliensis yeast cells. Med Mycol 2005;43:637-45.

101. Barbosa MS, Bao SN, Andreotti PF, de Faria FP, Felipe MS, dos Santos Feitosa L, Mendes-Giannini MJ, Soares CM. Glyceraldehyde-3-phosphate dehydrogenase of Paracoccidioides brasiliensis is a cell surface protein involved in fungal adhesion to extracellular matrix proteins and interaction with cells. Infect Immun 2006;74: 382-9.

102. Restrepo A, Tobòn AM. Paracoccidioides brasiliensis, Chapter 266. In: Mandell GL, Bennett's JE, Dollin R, editors. Principles and practice of infectious diseases. 6th ed. Philadelphia: Elsevier; 2005. p. 3062-8.

103. Puccia R, Carmona AK, Gesztesi JL, Juliano L, Travassos LR. Exocellular proteolityc activity of Paracoccidioides brasiliensis: cleavage of components associated with the basement membrane. Med Mycol 1998;36:345-8.

104. Patti JM, Höök M. Microbial adhesins recognizing extracellular matrix macromolecules. Curr Opin Cell Biol 1994;6(5):752-8.

105. González A, Gómez BL, Diez S, Hernández O, Restrepo A, Hamilton AJ, Cano LE. Purification and partial characterization of a Paracoccidioides brasiliensis protein with binding capacity to extracellular matrix proteins. Infect Immun 2005;73:2486-95.

106. Newman SL, Goote L, Gabay JE, Selsted ME. Identification of constituents of human neutrophil azurophil granules that mediated fungistasis against Histoplasma capsulatum. Infect Immun 2000;68:5668-72.

107. Drapier JC, Wietzerbin J, Hibbs JB. Interferon-g and tumor necrosis factor induce the L-arginine-dependent cytotoxic effector mechanism in murine macrophages. Eur J immunol 1988;18:1587-92.

108. Nathan CF. Secretory products of macrophages. J Clin Invest 1987;79:319-26.

109. McEwen JG, Brummer E, Stevens DA, Restrepo A. Effect of murine polymorphonuclear leukocytes against yeast form of Paracoccidioides brasiliensis. Am J Trop Med Hyg 1987;36:603-8.

110. Meloni-Bruneri LH, Campa A, Abdalla DS, Calich VL, Lenzi HL, Burger E. Neutrophil oxidative metabolism and killing of Paracoccidioides brasiliensis after air pouch infection of susceptible and resistant mice. J Leukoc Biol 1996;59:526-33.

111. Brummer E, Hanson LH, Stevens DA. Gamma interferon activation of macrophages for killing of Paracoccidioides brasiliensis and evidence for nonoxidative mechanism. Int J Immunopharmacol 1988;10:945-52.

112. González A, De Gregori W, Vélez D, Restrepo A, Cano LE. Nitric oxide participation in the fungicidal mechanism of gamma interferon-activated murine macrophages against Paracoccidioides brasiliensis conidia. Infect Immun 2000;68:2546-52.

113. Hibbs JB Jr, Taintor RR, Vavrin Z, Rachlin EM. Nitric oxide: a cytotoxic activated macrophage effector molecule. Biochem Biophys Res Commun 1988;157:87-94.

114. Hibbs JB Jr, Taintor RR, Vavrin Z. Macrophage cytotoxicity: role for L-arginine deaminase activity and imino nitrogen oxidation to nitrite. Science 1987;235:473-6. 
115. Hibbs JB Jr, Vavrin Z, Tainto RR. L-arginine is required for expression of the activated macrophage effector mechanism causing selective metabolic inhibition in target cells. J Immunol 1987;138:550-65.

116. Stuehr DJ, Kwon NS, Gross SS, Thiel BA, Levi R, Nathan CF. Synthesis of nitrogen oxides from L-arginine by macrophages cytosol: requirement for inducible and constitutive components. Biochem Biophys Res Commun 1989;161:420-6.

117. De Groote MA, Fang FC. NO inhibitions: antimicrobial properties of nitric oxide. Clin Infect Dis 1995;21: S162-5.

118. González A, Caro E, Aristizábal BH, Restrepo A, Cano LE. Expression of iNOS and $\mathrm{NF} \kappa \mathrm{B}$ in peritoneal macrophages activated with IFN- $\gamma$. Annu Rev Biomed Sci 2003;4:133-9.

119. González A, Aristizabal BH, Caro E, Restrepo A, Cano LE. TNF- $\alpha$-activated macrophages inhibit transition of Paracoccidioides brasiliensis conidia to yeast cells through a mechanism independent of nitric oxide. J Trop Med Hyg 2004;71:828-30.

120. Gonzalez A, Retrepo A, Cano LE. Role of iron in the nitric oxide-mediated fungicidal mechanism of IFN- $\gamma$ activated murine macrophages against Paracoccidioides brasiliensis conidia. Rev Inst Med Trop Sao Paulo 2007;49:11-6.

121. Bocca AL, Hayashi EE, Pinheiro AG, Furlanetto AB, Campanelli AP, Cunha FQ, Figueiredo F. Treatment of Paracoccidioides brasiliensis-infected mice with a nitric oxide inhibitor prevents the failure of cell-mediated immune response. J Immunol 1998;161:3056-63.

122. Nascimento FRF, Calich VLG, Rodrigues D, Russo M. Dual role of nitric oxide in paracoccidioidomycosis: essential for resistance but overproduction associated with susceptibility. J Immunol 2002;168:4593-600.

123. Akinbi HT, Eapaud R, Bhatt H, Weaver TE. Bacterial killing is enhanced by expression of lysozyme in the lungs of transgenic mice. J Immunol 2000;165:5760-6.

124. Biggar WD, Sturgess JM. Role of lysozyme in the microbial activity of rat alveolar macrophages. Infect Immun 1977;16:974-82.

125. Wu T, Samaranayake LP, Leung WK, Sullivan PA. Inhibition of growth and secreted aspartyl proteinase production in Candida albicans by lysozyme. J Med Microbiol 1999;48:721-30.

126. Nishiyama Y, Nakaoka C, Hiratani T, Abe S, Uchida K, Yamaguchi H. Synegry of lysozyme and lanoconazole on the morphology of Candida albicans. Electron Microsc 2001;50:41-9.

127. Brummer E, Castaneda E, Restrepo A. Paracoccidioidomycosis: an update. Clin Microbiol 1993;6:89-117.

128. Antachopoulos C, Roilides E. Cytokines and fungal infections. Br J Haematol 2005;129(5):583-96.

129. Rojas W. Moléculas que modulan la respuesta inmune, Chapter 12. In: Rojas W, Anaya JM, Aristizabal B, Cano LE, Gómez LM, Lopera D, editors. Inmunología de Rojas. 14 ed. Medellín: Corporación para Investigaciones Biológicas (CIB); 2007.

130. Kashino SS, Fazioli RA, Cafalli-Favati C, Meloni-Bruneri LH, Vaz CA, Burger E, Singer LM, Calich VL. Resistance to Paracoccidioides brasiliensis infection is linked to a preferential Th1 immune response, whereas susceptibility is associated with absence of IFN-gamma production. J Interferon Cytokine Res 2000;20(1):89-97.

131. Arruda C, Valente-Ferreira RC, Pina A, Kashino SS, Fazioli RA, Vaz CA, Franco MF, Keller AC, Calich VL. Dual role of interleukin-4 (IL-4) in pulmonary paracoccidioidomycosis: endogenous IL-4 can induce protection or exacerbation of disease depending on the host genetic pattern. Infect Immun 2004;72(7):3932-40.

132. Arruda C, Franco MF, Kashino SS, Nascimento FR, Fazioli Rdos A, Vaz CA, Russo M, Calich VL. Interleukin-12 protects mice against disseminated infection caused by Paracoccidioides brasiliensis but enhances pulmonary inflammation. Clin Immunol 2002;103(2): 185-95.

133. Souto JT, Aliberti JC, Campanelli AP, Livonesi MC, Maffei CM, Ferreira BR, Travassos LR, Martinez R, Rossi MA, Silva JS. Chemokine production and leukocyte recruitment to the lungs of Paracoccidioides brasiliensis-infected mice is modulated by interferongamma. Am J Pathol 2003;163(2):583-90.

134. Hemmann S, Graf J, Roderfeld M, Roeb E. Expression of MMPs and TIMPs in liver fibrosis-a systematic review with special emphasis on anti-fibrotic strategies. J Hepatol 2007;46:955-75.

135. Bárcenas CM, Cano LE, Cock AM, Martínez A, Restrepo A. Expresión de metaloproteinas y sus inhibidores de tejido en un modelo murino de fibrosis pulmonar. MedUNAB 2004;7:9-14.

136. Montenegro M, Franco M. Pathology. In: Franco M, Lacaz C, Restrepo A, del Negro G, editors. Paracoccidioidomycosis. Boca Raton: CRC Press; 1994. p. 136-8.

137. Moreira AP, Campanelli AP, Cavassani KA, Souto JT, Ferreira BR, Martinez R, Rossi MA, Silva JS. Intercellular adhesion molecule-1 is required for the early formation of granulomas and participates in the resistance of mice to the infection with the fungus Paracoccidioides brasiliensis. Am J Pathol 2006;169(4):1270-81.

138. Scott PA, Sher A. Immunoparasitology. In: Paul WE, editor. Fundamental parasitology. 3rd ed. New York: Raven Press; 1993. p. 1179-210.

139. Goodwin RA, Nickell JA, Dez Prez RM. Mediastinal fibrosis complicating healed primary histoplasmosis and tuberculosis. Medicine 1972;51:227-32.

140. Perez MI, Kohn S. Systemic sclerosis. J Am Acad Dermatol 1993;28:525-47.

141. Thrall RS, McCormick RM Jr, McReynolds RA, Ward PA. Bleomycin induced pulmonary fibrosis in the rat: inhibition by indomethacin. Am J Pathol 1979;95:117-27.

142. Cantin AM, Boilean R, Begin R. Increased procollagen III amino terminal peptide-related antigens and fibroblast growth signals in the lung of patients with idiopathic pulmonary fibrosis. Am Rev Respir Dis 1988;137: 572-9.

143. Crystal R, Bitterman P, Rennard SI, Hance AK, Keogh BA. Interstitial lung disease of unknown cause. Disorder characterized by chronic inflammation of the lower respiratory (first part). N Engl J Med 1984;310:154-66.

144. Crystal R, Bitterman P, Rennard SI, Hance AK, Keogh BA. Interstitial lung disease of unknown cause. Disorder characterized by chronic inflammation of the lower 
respiratory tract (second part). N Engl J Med 1984;310: 235-44.

145. Fridman SL. The cellular basis of hepatic fibrosis. Mechanisms and treatment strategies. N Engl J Med 1993;355:1835.

146. Bitterman PB, Adelberg S, Crystal RG. Mechanisms of pulmonary fibrosis: spontaneous release of alveolar macrophage derived growth factor in the interstitial lung disorders. J Clin Invest 1993;72:1810-3.

147. Bitterman PB, Rennard SI, Hunninghake G, Crystal RG. Human alveolar macrophase growth factor for fibroblasts. Regulation and partial characterization. J Clin Invest 1982;70:806-22.

148. Wynn TA. Common and unique mechanisms regulate fibrosis in various fibroproliferative diseases. J Clin Invest 2007; 117(3):524-9.

149. Buttery LDK, Evans TJ, Springall DR, Carpenter A, Cohen J, Polak JM. Immunochemical localization of inducible nitric oxide synthase in endotoxin-treated rats. Lab Invest 1994;71:755-64.

150. Stenger S, Thuring H, Rollinghoff M, Bogdan C. Tissue expression of inducible nitric oxide synthase is closely associated with resistance to Leishmania major. J Exp Med 1994;180:783-93.
151. Goldman D, Cho Y, Zhao ML, Casadevall A, Lee SC. Expression of inducible nitric oxide synthase in rat pulmonary Cryptococcus neoformans granulomas. Am J Pathol 1996;148:1275-82.

152. Beaven MA, Gordon JW, Jacobsen S, Severs WB. A specific and sensitive assay for aminoguanidine: its application to a study of the disposition of aminoguanidine in animal tissues. J Pharmacol Exp Ther 1969;165: 14-22.

153. Moncada S, Feelisch M, Busse R, Higgs EA. The biology of nitric oxide. London: Portland Press; 1994.

154. Chan J, Tanaka K, Carroll D, Flynn J, Bloom BR. Effects of nitric oxide synthase inhibitors on murine infection with Mycobacterium tuberculosis. Infect Immun 1995;63: 736-40.

155. Flynn JL, Scanga CA, Tanaka KE, Chan J. Effects of aminoguanidine on latent murine tuberculosis. J Immunol 1998;160:1796-803.

156. Beckerman KP, Rogers HW, Corbett JA, Schreiber RD, McDaniel ML, Unanue ER. Release of nitric oxide during the $\mathrm{T}$ cell-independent pathway of macrophage activation. Its role in resistance to Listeria monocytogenes. J Immunol 1993;150:888-95. 